\title{
Effects of weather on breeding success of Ashy prinia (Prinia socialis) in Manigram of Tilottama Municipality, Nepal
}

\author{
Shova Adhikari ${ }^{1}$, Hari Prasad Sharma ${ }^{1,2,}$, Ramji Gautam ${ }^{1,3}$, Rajendra Basaula ${ }^{1,3}$ \\ ${ }^{1}$ Central Department of Zoology, Institute of Science and Technology, Tribhuvan University, Kirtipur, Nepal \\ ${ }^{2}$ Nepal Zoological Society, Kathmandu, Nepal \\ ${ }^{3}$ Prithvi Narayan Campus, Pokhara, Nepal
}

\begin{abstract}
Breeding success of species, including nest construction to chick fledgling, is a major determining factor for the conservation of bird species. Ashy prinia (Prinia socialis), a small-sized, insectivorous bird, which is widely distributed in South East Asia is less explored for its breeding ecology. This study was performed in natural habitats of Tilottama municipality, Nepal, and the data such as nest characteristics, clutch size, activities of parents on nest were collected with regular monitoring of nest from the beginning of its construction to chicks fledgling. Ashy prinia constructed nests on bushes of shrubs and grasses using materials like grass, nylon threads, small twigs, cotton swag and some threads. The clutch size was four; and the average length and breadth of eggs were $1.6 \mathrm{~cm}$ and $1.2 \mathrm{~cm}$, respectively. The nest was able to fledge chicks successfully, and their breeding success was $75 \%$, determined by the activities of parents, local weather conditions mainly cloud cover, temperature and wind. In addition, the breeding success of the Ashy prinia might be due to monogamous parental cares in which both parents maintained the microclimatic condition of the nest from incubation period to chick fledgling.
\end{abstract}

Keywords: Ashy prinia, breeding success, chick fledgling, clutch size, monogamous

\section{Introduction}

Knowledge on causes and consequences of variation in avian reproductive strategies seems major focus on their life history traits (Martin, 1987; Roff, 1992; Stearns, 1992) which is important not only for ecological, evolutionary, and behavioral studies (Stutchbury \& Morton, 2001, 2008), but also for systematics, physiology, and conservation biology (Begon et al., 2006; Bennett \& Owens, 2002; Brown, 1987). Information on breeding biology including nest building in birds require extreme skills of engineering (Marini et al., 2012). Nests of birds are also having huge variations in their size, shape, structure, construction materials, construction pattern, selection of site for nest, and nest architecture (Goodfellow, 2011; Mainwaring et al., 2014). For the breeding success in birds, the nest survival is the most important variable affecting fitness with direct consequences on their population dynamics (Cresswell, 2011). The ornithological literatures often emphasize that the population declining in passerines is mainly due to breeding failure, which is noticed after loss of eggs or chicks through nest predation (Martin, 1988a; Martin, 1988b; Newton, 1998; Ricklefs, 1969). Due to seasonal variation in predator abundance and activity, nest predation is known to vary with nesting date (Cox et al., 2012; Roos, 2002; Schaub et al., 1992). Investigating the factors acting on breeding biology and nest survival is of great importance for assessing the breeding success of bird species.
Nepal is rich in the avifauna including 886 bird species $(8.87 \%$ of global bird species) with one endemic species Spiny babbler (Turdoides nipalensis) (DNPWC, 2018; Grimmett et al., 2016). Till date, eight species of the birds have extinct from Nepal (Baral et al., 2012). Among the bird species found in Nepal, 42 species are globally threatened and 35 are under the near-threatened category (DNPWC, 2018; Grimmett et al., 2016). Breeding success is one of the major factors acting on increased bird population (Grant et al., 1999). The major habitat of birds in Nepal is recorded in forests, grasslands, and wetlands; more than $77 \%$ habitat of breeding birds are inhabitant in bushes and forest (Grimmett et al., 2000). Within these habitats the Ashy prinia (Prinia socialis) inhabits in most of the habitats including along forest edges, dry open-grasslands, openwoodlands, scrub, urban gardens, and agricultural landscapes (Grimmett et al., 2016).

Globally, 27 species of prinia have been recognized (Alström et al., 2020) among which nine species are recorded from Nepal (Grimmet et al., 1998). Ashy prinia is a small bodied sparrow size insectivorous bird, classified under the Passeriformes species of family Cisticolidae. The species is widely distributed in Bangladesh, Bhutan, India, Nepal, Pakistan, and Sri Lanka (BirdLife International, 2016) upto $1500 \mathrm{~m}$ of elevation in the Himalayas, and up to

\footnotetext{
* Corresponding author: hpsharma@cdztu.edu.np
} 
$2000 \mathrm{~m}$ in southern India (Ali, 2002). Its features such as small body size (13-14 cm long wings), distinct colours of longish graduated cream tail tipped with black subterminal spots with upright tail make it distinct with other birds (Balkhande et al., 2017). They usually produce a call as repetitive sound "tchup, tchup, tchup or zeet-zeet-zeet or nasal tee-tee-tee". Or sometimes a sound like "electric sparks" which is thought to be produced by the wings or probably by beak (Rasmussen et al., 2005; Uttangi, 1991).

The species is monogamous and both the male and female participate for incubation and chicks feeding (Karthikeyan, 1993). Male and female form a pair during breeding seasons, but they are solitary in other times (Inskipp et al., 2016). Its nesting season mostly starts after the monsoon season, and ranges from March to September. Its population is assumed as stable, however its ecology, population and existing threats due to nest failure is almost unknown and the species is listed under Least Concern (Birdlife International, 2016). The factors acting on the nesting behavior can provide some information to develop the conservation action or management plan for the conservation of species. The breeding success of nest is determined by the orientation of the nest (Burton, 2006), parental care (Willams, 2018) and microclimatic condition of the nest generated by parents (Mueller et al., 2019). Knowledge on breeding biology and ecology of birds is essential for the development of efforts to stop the ongoing loss of bird species. Till date no more information is available on the factors acting on the nesting ecology of species from Nepal. Therefore, we aimed to identify the breeding success of nest and effects of weather on the occurrence of parents of Ashy prinia.

\section{Materials and Methods \\ Study Area}

The study area is located at Manigram of Tilottama Municipality $\left(27^{\circ} 41^{\prime} 10.9896^{\prime \prime} \mathrm{N}\right.$ and $\left.83^{\circ} 25^{\prime} 56.7336 " \mathrm{E}\right)$ in Rupandehi district of Lumbini Province, Nepal (Fig. 1). It comprises an area of 126.2 square $\mathrm{km}$. The study area has been noticed with rapid transformation in infrastructure development and land-use change from open area/or forest or grassland to build up area.

\section{Data Collection}

We searched the occurrence of Ashy prinia in Manigram, Rupandehi from 25 February to 26 March 2020 to find their potential sites of breeding grounds. We observed Ashy prinia by direct observation and using Bushnell, 10X42 mm binoculars. After we confirmed their nest, we monitored them regularly until the chick fledgling or failure. We followed five pairs of Ashy prinia for more than a month with expecting a breeding potentiality. However, only two pairs were able to construct nest during this period. Once a nest was located, we immediately observed the contents of the nest and observed activities of birds on nest and egg laying date with the help of binoculars without any disturbances. We collected data on nest characteristics such as size of the nest, height of nest above the ground, and nesting plant species, egg laying date, clutch size, length and breadth of eggs, male and female's presence on nest during incubation time, hatching date, the number of hatchlings,



Figure 1 Study area with nest location at Manigram, Tilottama Municipality of Lumbini Province, Nepal 
Nep J Environ Sci (2020), 8, 11-16

https://doi.org/10.3126/njes.v8i1.35404

fledgling date, and the number of fledglings. We measured the size, depth and height (from the ground surface to the position) of the nest using measuring scale. We counted the number of eggs (clutch size) in each nest. We measured the length and breadth of eggs using Vernier Caliper. For egg measurement we used only the egg shell which were casted after hatching. However, in this project, two eggs were fell down and we used these eggs to measure the length and breadth. All the photographs of parents Ashy prinia, eggs, juvenile and nest of prinia were taken by using EOS Rebel T7 DSLR camera.

In addition, we noticed the presence/absence of Ashy prinia on the nest between 6.00 am to $6.00 \mathrm{pm}$ from nest construction to chick fledgling at every 15 minutes interval. We observed the presence and absence of male and female Ashy prinia in and around the nest (Figs. 2a and 2b). We recorded the presence of either male or female or both on the nest for incubating, guarding and caring of chicks on nest. We also noted the presence of parents if these are present in and around $30 \mathrm{~m}$ of nest. Furthermore, we noted the daily weather of the study area like temperature $\left({ }^{\circ} \mathrm{C}\right)$, humidity (g. $\left.\mathrm{kg}^{-1}\right)$, dew point $\left({ }^{\circ} \mathrm{C}\right)$, cloud cover (oktas) and wind $\left(\mathrm{ms}^{-1}\right)$ of nest of Ashy prinia at each 15 min interval with the help of Android mobile. These data were recorded from $50 \mathrm{~m}$ away from the nest to avoid potential disturbances to the nest.

\section{Data analysis}

We calculated breeding success on the basis of number of eggs and successful fledglings. As it lays four eggs, the breeding success is total successful fledglings divided by four times of the total number of nests. We used a Generalized Linear Model to identify the effects of weather such as temperature, humidity, dew point, cloud cover and wind on the presence of parents on the nest. All analysis were performed in R Program (R Core Team, 2019).

\section{Results and Discussion}

On the last week of April 2020, we found two adult pairs of Ashy prinia which were continuously visiting the bushes where they were beginning to construct the nest with adding new fibres to it. We found one nest on thick bush of Perilla (Perilla fructescens) annual herb plant, and another on Lantana (Lantana camara) a perennial shrub plant. The bird constructed a nest at a height of about $7.4 \mathrm{~m}$ from the ground on the bushes of Perilla (Figs. $3 \mathrm{a}$ and 3b). They constructed a nest with the stitched leaves of nest constructed plants together with fibres and webs, and lined with fine thin fibres and twigs. Both the male and female partners had joint efforts and almost equal shares for nest construction. Not only in Ashy prinia, other bird species such as long-tailed tit make strong collaboration between male and female for nest construction (Healy et al. 2008). We found the materials like grass, nylon threads, small twigs, cotton swag and some threads used for nest construction.

The average width and depth of the constructed nest was $8.8 \mathrm{~cm}$ and $7.9 \mathrm{~cm}$, respectively. In both nest the Ashy prinia laid eggs between 8 and 10 May 2020. We noticed the four crimson-red eggs (clutch size $=4$ ) in each nest (Fig. 4a). Only six chicks were hatched out from these two nests within 10-12 days of egg laying (Figs. 4b, 5a and 5b). Two eggs were fell down from the nest of Perilla plant. Both male and female incubated for 10-12 days. The average length and breadth of egg was $1.6 \mathrm{~cm}$ and $1.2 \mathrm{~cm}$, respectively.

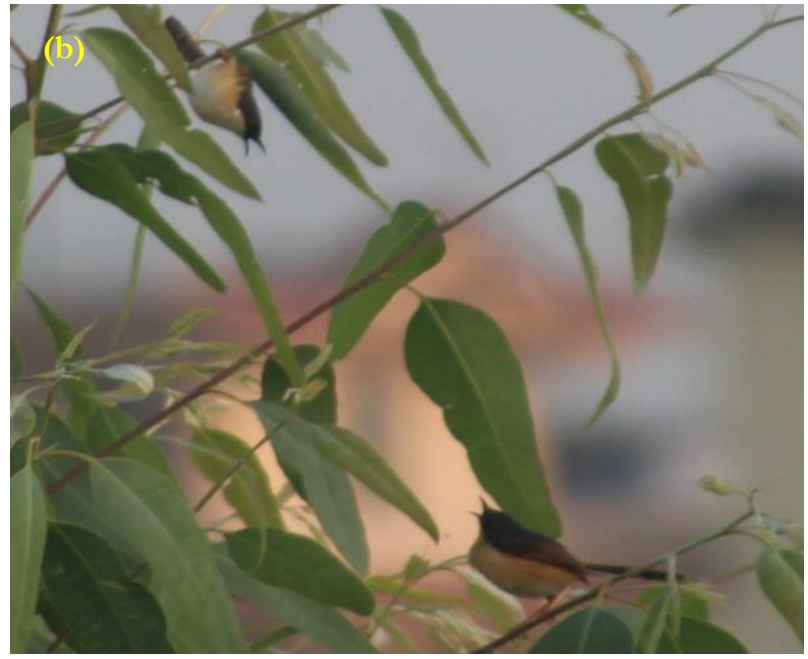

Figure 2 Ashy prinia, the study species (a); male (upper) and female (lower) adults of Ashy prinia (b) 
Nep J Environ Sci (2020), 8, 11-16

https://doi.org/10.3126/njes.v8i1.35404
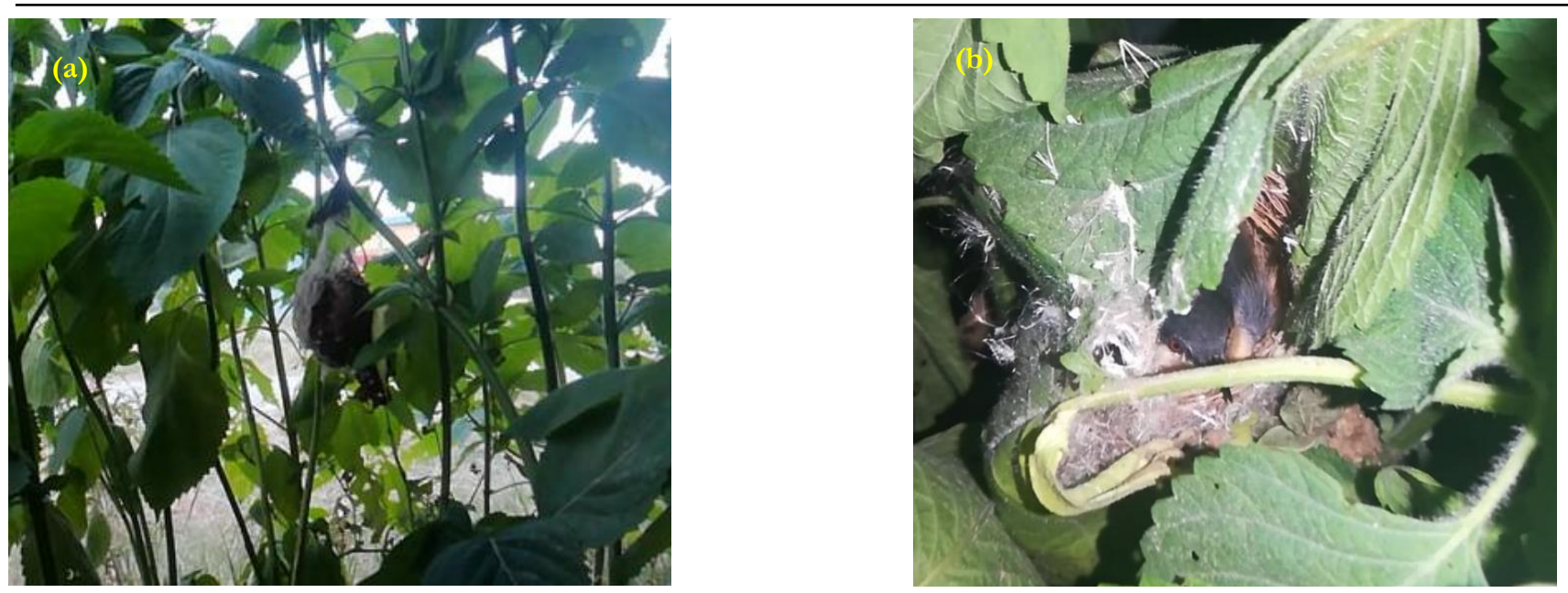

Figure 3 Whole plant of Perilla along with nest (a); side view of the Prinia nest (b)

In our study the breeding success of Ashy prinia was good because they were able to fledge out their chicks from studied nests, however all laid eggs were not able to hatch out because of accidentally lost eggs. Its breeding success was $75 \%$. It might be due to construction of nest in weak stemed herb plants Perilla, and small nest depth, and also the immature parents who have little experiences for nest construction. Generally, the breeding success of birds is influenced by the orientation of the nest (Burton, 2006).

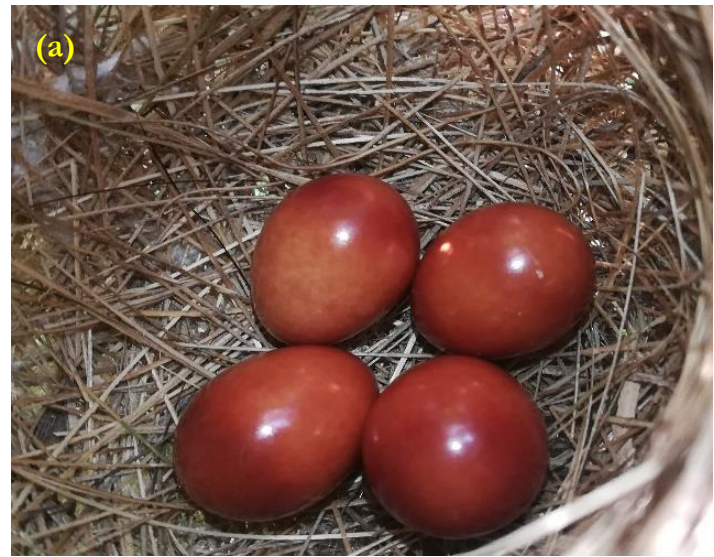

Figure 4 Nest with a clutch of eggs (4 eggs) (a); nest with four hatchlings (b)
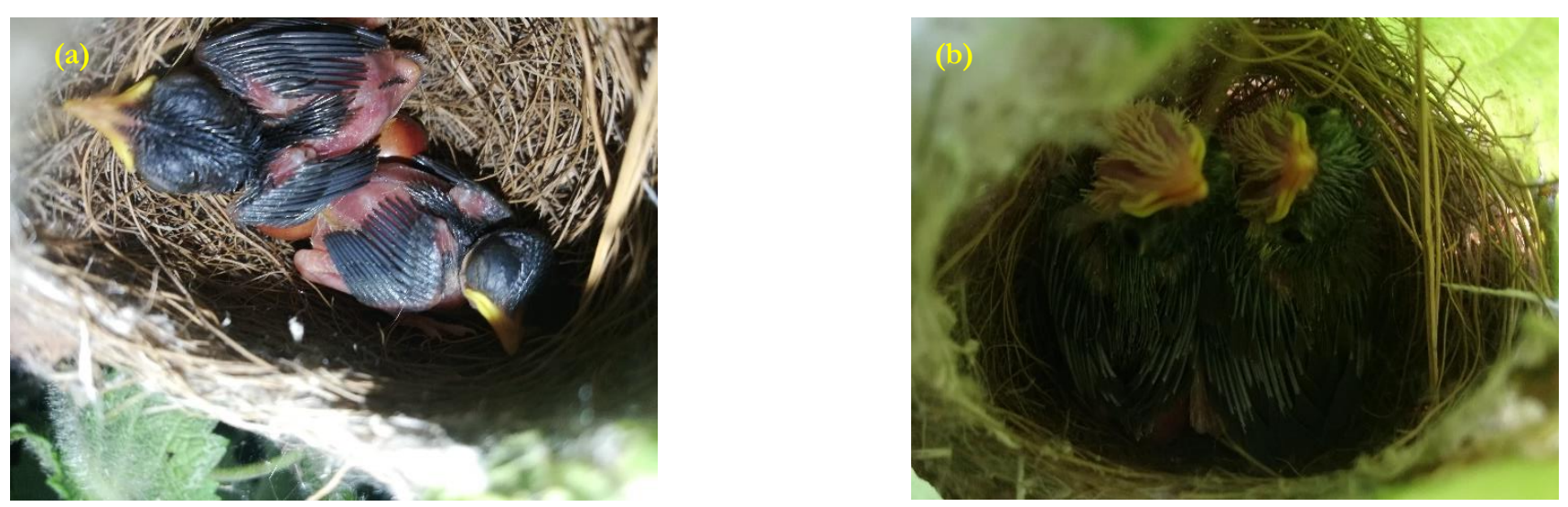

Figure 5 Eight-day old chicks (a); twelve-day old chicks in the nest (b)
This type of loss can occur for many times to the Ashy prinia because they construct nest in short bushes and grasses. The breeding success in Ashy prinia during this study period might be due to monogamous nature of species (Karthikeyan, 1993), in which both male and female incubate the eggs and feed the chicks, and defense the territory from the predators (Bart \& Tornes, 1989). We did not notice any sign of the predators in and around the nesting location during this period.

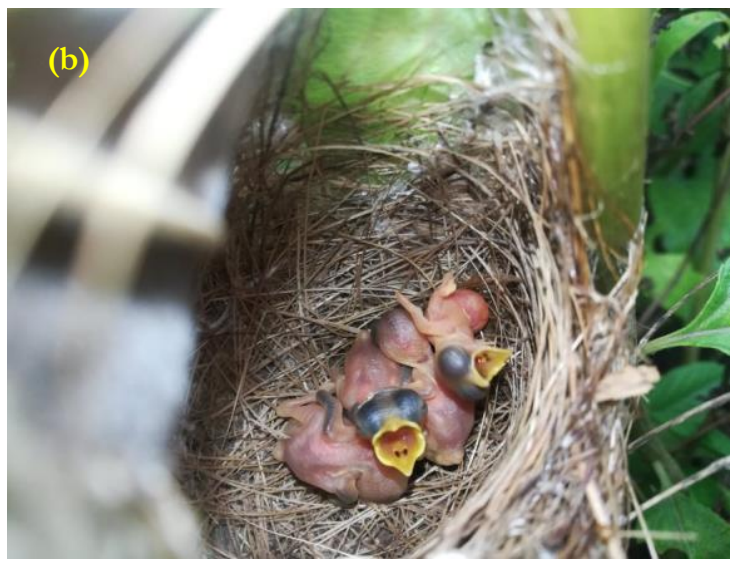


Nep J Environ Sci (2020), 8, 11-16

https://doi.org/10.3126/njes.v8i1.35404

Table 1 Logistic regression model describing the occurrence of parents Ashy prinia on nest. Presence absence of parent Ashy prinia on the nest were used as response variables and climatic variables temperature $\left({ }^{\circ} \mathrm{C}\right)$, humidity $\left(\mathrm{g} \cdot \mathrm{kg}^{-1}\right)$, dew point $\left({ }^{\circ} \mathrm{C}\right)$, cloud cover (oktas) and wind $\left(\mathrm{ms}^{-1}\right)$ as independent variables. Model-averaged parameter estimates and lower and upper $95 \%$ confidence limits describing the effects of weather on the occurrence of parents on nest. Parameter estimates were averaged from all models reported.

\begin{tabular}{lllllll}
\hline & Estimate & SE & Lower limit & Upper limit & Z & $p$ \\
\hline (Intercept) & 2.124 & 2.368 & -2.518 & 6.765 & 0.897 & 0.369 \\
Cloud cover & 0.014 & 0.006 & 0.003 & 0.026 & 2.491 & 0.013 \\
Temperature & -0.158 & 0.051 & -0.257 & -0.059 & 3.124 & 0.002 \\
Wind & -0.141 & 0.063 & -0.264 & -0.017 & 2.229 & 0.026 \\
Humidity & 0.018 & 0.016 & -0.014 & 0.049 & 1.113 & 0.266 \\
\hline
\end{tabular}

Weather is one of the driving factors for nest failure (Flaspohler et al., 2001). In our study, the weather factors such as temperature and wind has negative effects on the occurrence of parents Ashy prinia on the nest, however cloud cover has significantly positive effects (Table 1). Parents stay on nest with increasing cloud cover, probably they protect the nestlings against decreasing temperature. It means their occurrences in nest decreases with increasing temperature. Birds leave the nest with increasing the temperature and their return to the nest is determined by the memory of the heat position (Wesley, 1994). In addition, their occurrences in the nest decreases with increasing the wind speed. Ashy prinia constructs nest on the grasses, therefore during windy condition they won't be at nest; probably the nest goes with more swinging and damages. All these factors change the microclimatic condition of the nest, which drives the reproductive success or failure. The microclimate of the nest during the incubation period is generally influenced by the occurrence of parent birds (Mueller et al., 2019; Reid et al., 2000), however we did not study the availability of food and their influence on the occurrence of parents on nest.

\section{Conclusion}

The breeding success of Ashy prinia is determined by the occurrence of parents on the nest from egg hatching to chick fledging because during this period the parents maintain the microclimatic condition of the nest. In addition, the breeding success was $75 \%$ attributable to the monogamous parental cares in Ashy prinia, i.e., care by both male and female, so they are able to feed chick abundantly. Because of the nature of the nest construction in grassland area having bush, we recommend to prevent any disturbances in the area.

\section{Acknowledgements}

Authors thank Central Department of Zoology for providing logistic arrangements during this study.

\section{References}

Ali, S. (2002). The Book of Indian Birds. 13 $3^{\text {th }}$ (Revised) ed. Mumbai: Bombay Natural History Society \& Oxford University Press, USA.

Alström, P., Rasmussen, P.C., Sangster, G., Dalvi, S., Round, P.D., Zhang R., Yao, C.T., Irestedt, M., Le Manh, H., Lei, F., \& Olsson, U. (2020). Multiple species within the Striated Prinia Prinia crinigera-Brown Prinia $P$. polychroa complex revealed through an integrative taxonomic approach. Ibis, 162(3), 936-967.

Balkhande, J., Chavhan, A., \& Issak, S.A. (2017). Study of nesting pattern and breeding biology of Prinia socialis in forest office of Bhokar Dist. Nanded (Maharashtra) India. International Journal of Life Sciences, 5(4), 635-638.

Baral, H.S., Regmi, U.R., Poudyal, L.P., \& Acharya, R. (2012). Status and conservation of birds in Nepal. Biodiversity Conservation in Nepal: A Success Story. Department of National Parks and Wildlife Conservation, Kathmandu, pp. $71-100$.

Bart, J., \& Tornes, A. (1989). Importance of monogamous male birds in determining reproductive success. Behavioral Ecology and Sociobiology, 24(2), 109-116.

Begon, M., Townsend, C.R., \& Haper, J.L. (2006). Ecology: from individuals to ecosystems. Blackwell Publishing, Malden, Massachusetts, USA.

Bennett, P.M., \& Owens, I.P.F. (2002). Evolutionary ecology of birds: life histories, mating systems and extinction. Oxford University Press.

BirdLife International. (2016). Prinia socialis. The IUCN Red List of Threatened Species.

Brown, J.L. (1987). Helping and communal breeding in birds. Princeton Univ. Press, Princeton, New Jersey, USA.

Burton, N.H. (2006). Nest orientation and hatching success in the tree pipit Anthus trivialis. Journal of Avian Biology, 37(4), 312-317.

Cox, W.A., Thompson, F.R., \& Faaborg, J. (2012). Landscape forest cover and edge effects on songbird nest predation vary by nest predator. Landscape Ecology, 27(5), 659-669.

Cresswell, W. (2011). Predation in bird populations. Journal of Ornithology, 152(1), 251-263.

DNPWC. (2018). Department of National Parks and Wildlife Conservation, Nepal. Web: http://dnpwc.gov.np/ (Accessed on 19 February, 2020).

Grant, M.C., Orsman, C., Easton, J., Lodge, C., Smith, M., Thompson, G., Rodwell, S., \& Moore, N. (1999). Breeding success and causes of breeding failure of curlew Numenius arquata in Northern Ireland. Journal of Applied Ecology, 36(1), 59-74.

Flaspohler, D.J., Temple, S.A., \& Rosenfield, R.N. (2001). Species-specific edge effects on nest success and breeding bird density in a forested landscape. Ecological Applications, 11(1), 32-46

Goodfellow, P. (2011). Avian architecture: How birds design, engineer, and build. Princeton University Press. 
Grimmett, R., Inskipp, C., \& Inskipp, T. (1998). Birds of the Indian Subcontinent. $1^{\text {st }}$ ed. London: Christopher Helm, A \& C Black, 1-888.

Grimmett, R., Inskipp, C., Inskipp, T., \& Baral, H.S. (2016). Birds of Nepal. Bloomsbury Publishing.

Grimmett, R., Inskipp, C., Inskipp, T., \& Baral, H.S. (2000). Birds of Nepal. Helms Field Guide. Revised edition, Christopher Helm, London, UK.

Healy, S., Walsh, P., \& Hansell, M. (2008). Nest building by birds. Current Biology, 18(7), R271-R273.

Inskipp, C., Baral, H.S., Phuyal, S., Bhatt, T.R., Khatiwada, M., Inskipp, T., Khatiwada, A., Gurung, S., Singh, P.B., Murray, L., Poudyal, L., \& Amin, R. (2016) The status of Nepal's Birds: The national red list series. Zoological Society of London, UK.

Karthikeyan, S. (1993). Monogamy in Ashywren Warbler Prinia socialis: How much do sexes share domestic duties? Bird Conservation: Strategies for the Nineties and Beyond. In Verghese, A., Sridhar, S., \& Chakravarthy, A.K., (eds.), Bangalore: Ornithological Society of India, 200201.

Mainwaring, M.C., Hartley, I.R., Lambrechts, M.M., \& Deeming, D.C. (2014). The design and function of birds' nests. Ecology and Evolution, 4(20), 3909-3928.

Marini, M.Â., Borges, F.J., Lopes, L.E., Sousa, N.O., Gressler, D.T., Santos, L.R., Paiva, L.V., Duca, C., Manica, L.T., Rodrigues, S.S., \& França, L.F. (2012). Breeding biology of birds in the Cerrado of central Brazil. Ornitologia Neotropical, 23, 385-405.

Martin, T.E. (1987). Food as a limit on breeding birds: a lifehistory perspective. Annual Review of Ecology and Systematics, 18(1), 453-487.

Martin, T.E. (1988a). Processes organizing open-nesting bird assemblages: competition or nest predation? Evolutionary Ecology, 2, 37-50.

Martin, T.E. (1988b). On the advantage of being different: nest predation and the coexistence of bird species. Proceeding of National Academy of Science, USA, 85, 2196 2199.

Mueller, A.J., Miller, K.D., \& Bowers, E.K. (2019). Nest microclimate during incubation affects posthatching development and parental care in wild birds. Scientific Reports, 9(1), 1-11.
Newton, I. (1998). Population Limitation in Birds. London: Academic Press.

R Core Team. (2019). The R Project for Statistical Computing, Vienna, Austria. https://www.Rproject.org.

Rasmussen, P.C., Anderton, J.C., \& Edicions, L. (2005). Birds of south Asia: the Ripley guide. British Birds, 98, 609-613.

Reid, J.M., Monaghan, P., \& Ruxton, G.D. (2000). Resource allocation between reproductive phases: the importance of thermal conditions in determining the cost of incubation. Proceedings of the Royal Society of London. Series B: Biological Sciences, 267(1438), 37-41.

Ricklefs, R.E. (1969). An analysis of nesting mortality in birds. Smithsonian Contributions to Zoology. Smithsonian Institution Press City of Washington, USA.

Roff, D.A. (1992). The evolution of life histories: theory and analysis. Chapman and Hall, New York, USA.

Roos, S. (2002). Functional response, seasonal decline and landscape differences in nest predation risk. Oecologia, 133(4), 608-615.

Schaub, R., Mumme, R.L., \& Woolfenden, G.E. (1992). Predation on the eggs and nestlings of Florida Scrub Jays. The Auk, 109(3), 585-593.

Stearns, S.C. (1992). The evolution of life histories. Oxford University Press, Oxford, UK.

Stutchbury, B.J., \& Morton, E.S. (2001). Behavioral ecology of tropical birds. Academic press, San Diego, CA, USA.

Stutchbury, B.J., \& Morton, E.S. (2008). Recent advances in the behavioral ecology of tropical birds. The Wilson Journal of Ornithology, 120(1), 26-37.

Uttangi, J.C. (1991). Electric sparks from Ashy Wren Warbler. Newsletter for Birdwatchers, 31(8), 14.

Wesley, H.D. (1994). Nest-temperature regulation during incubation in Ashy Wren-Warbler. Newsletter for Birdwatchers, 34(2), 29-31.

Williams, T.D. (2018). Physiology, activity and costs of parental care in birds. Journal of Experimental Biology, 221(17), jeb169433. 